\title{
Health as dignity: political ecology, epistemology and challenges to environmental justice movements
}

\author{
Marcelo Firpo Porto ${ }^{1}$ \\ Diogo Rocha Ferreira \\ Renan Finamore
}

National School of Public Health / Oswaldo Cruz Foundation, Brazil

\begin{abstract}
The article discusses conceptual and methodological issues related to environmental risks and health problems, in the context of environmental injustice and conflicts. In doing so, we use the conceptual frameworks of political ecology and what we call political epistemology. We propose a comprehensive vision of health that relates not only to illness and death, but also to life, nature, culture and fundamental human rights. We summarize this as health and dignity, echoing the voices of countless people who have been fighting for the right to life and the commons, and against the impacts of mining, agribusiness and the oil industry. Therefore our concept of health is intrinsically related to the capacity of affected communities and their democratic allies to face environmental conflicts (the exploitation of natural resources and the workforce with the systematic violation of rights related to work, land, environment and health). Mobilizations for environmental justice also struggle for the autonomy of communities, their cultures, and the right to maintain indigenous or peasant livelihoods. The way knowledge is produced plays a fundamental role in environmental justice mobilizations since issues of power are related to epistemological disputes and counter-hegemonic alternatives. Political epistemology is an alternative way of confronting crucial questions related to knowledge production, uncertainties and the manipulations of those who generate environmental injustices. Finally, we point to some strategies for strengthening the shared production of knowledge and the mobilization of communities that organize to confront environmental injustices.
\end{abstract}

Key words: political epistemology, political ecology of health, health and dignity

\section{Résumé}

L'article traite des questions conceptuelles et méthodologiques liées aux risques environnementaux et aux problèmes de santé, dans le contexte de l'injustice environnementale et des conflits. Ce faisant, nous utilisons les cadres conceptuels de l'écologie politique et ce que nous appelons «épistémologie politique». Nous proposons une vision globale de la santé qui concerne non seulement la maladie et la mort, mais aussi la vie, la nature, la culture et les droits humains fondamentaux. Nous résumons ceci comme «la santé et la dignité», faisant écho aux voix d'innombrables personnes qui ont lutté pour le droit à la vie et les biens communs, et contre les impacts de l'industrie minière, l'agroalimentaire et l'industrie pétrolière. Par conséquent, notre concept de santé est intrinsèquement lié à la capacité des communautés touchées et de leurs alliés démocratiques de faire face à des conflits environnementaux (exploitation des ressources naturelles et de la main-d'œuvre avec violation systématique des droits liés au travail, à la terre, à l'environnement et à la santé). Les mobilisations pour la justice environnementale luttent également pour l'autonomie des communautés, leurs cultures et le droit de maintenir des moyens de subsistance indigènes ou paysans. La façon dont la connaissance est produite joue un rôle fondamental dans la mobilisation de la justice environnementale puisque les questions de pouvoir sont liées à des conflits épistémologiques et à des alternatives contre-hégémoniques. L'épistémologie politique est un moyen alternatif de confronter les questions cruciales liées à la production des connaissances, les incertitudes et les manipulations de ceux qui génèrent des injustices environnementales. Enfin, nous soulignons certaines stratégies pour renforcer la production partagée de connaissances et la mobilisation des communautés qui s'organisent pour faire face aux injustices environnementales.

Mots clés: épistémologie politique, écologie politique de la santé, de la santé et de la dignité

\footnotetext{
${ }^{1}$ Dr. Marcelo Firpo Porto, Diogo Rocha Ferreira and Dr. Renan Finamore, National School of Public Health / Oswaldo Cruz Foundation (ENSP/FIOCRUZ), Brazil. Email: marcelo.firpo at" ensp.fiocruz.br. Acknowledgements: EJOLT, EU 7th Framework Programme grant 266642 and editors and reviewers. This is the sixth article in Creighton Connolly, Panagiota Kotsila, and Giacomo D'Alisa (eds.) 2016. "Tracing narratives and perceptions in the political ecology of health and disease", Special Section of the Journal of Political Ecology 24: 1-124.
} 


\section{Resumen}

El artículo discute temas conceptuales y metodológicos sobre los riesgos ambientales y problemas de salud en contextos de injusticias y conflictos ambientales utilizando como referencia la ecología política y lo que llamamos epistemología política. Proponemos una visión integral de la salud que se relaciona no sólo con la enfermedad y la muerte, pero con la vida, la naturaleza, la cultura y los derechos fundamentales. Resumimos esto en la expresión "Salud y Dignidad", haciéndose eco de las voces de innumerables personas que han estado luchando por el derecho a la vida y los bienes comunes, y en contra de los impactos de los sectores económicos como la minería, la agroindustria y la industria petrolera. Por lo tanto nuestro concepto de salud está intrínsecamente relacionado con la capacidad de las comunidades afectadas y sus alianzas democráticas para hacer frente a los conflictos ambientales. Estos revelan la explotación de los recursos naturales y dos trabajadores con la violación sistemática de los derechos relacionados con diferentes aspectos: el trabajo, la tierra, el medio ambiente y la salud. Movilizaciones por la justicia ambiental también luchan por la autonomía de las comunidades, sus culturas, el derecho a mantener sus medios de vida como indígenas o campesinos, entre otros. La forma en cómo el conocimiento se basa y es producido juega un papel fundamental para la movilización de justicia ambiental ya que las cuestiones de poder están relacionadas con disputas epistemológicas y alternativas contra hegemónicas de sociedad. Utilizamos la epistemología política como una forma alternativa de hacer frente a cuestiones cruciales relacionadas con la producción de conocimiento, así como las incertidumbres y sus manipulaciones de parte de los que generan injusticias ambientales. Señalamos a las estrategias para el fortalecimiento de la producción compartida de conocimientos y el protagonismo de las comunidades que se movilizan para hacer frente a las injusticias ambientales.

Key words: political epistemology, political ecology of health, health and dignity

\section{Introduction: a political ecology of health}

I am afraid beyond my duty as a citizen, of the impulse that I have when I see an injustice. It takes away my fear. It gives me the courage to fight, because man is what he is. So if you have the courage to fight, fight. Better you die trying, than to die silent.

José Cláudio Ribeiro da Silva, leader of an agro-extractive reserve murdered with his companion, Maria do Espírito Santo, on 24th May 2011. Both were popular environmentalists who fought to defend the forest and settled in Praialta-Piranheira Project in New Ipixuna, Pará.

This article offers a comprehensive vision of health, health and dignity, that links life, nature, culture and fundamental human rights. We offer our analysis to support social activists, affected communities, and organizations and researchers jointly engaged in movements for environmental justice (EJ) (Porto, Finamore and Rocha 2015). It is based on the report Health as dignity: risks, health and mobilizations for environmental justice, written for the international project EJOLT, which addresses health concerns at multiple scales, and particularly in countries of the 'Global South'. ${ }^{2}$

From the point of view of political ecology, health can be seen as one important dimension of environmental conflicts and EJ mobilizations in the context of a growing social metabolism, meaning the increasing throughput of energy and materials and production of waste (Hornborg et al. 2007; MartinezAlier 2009). A key task for global EJ movements is one of connecting local and communitarian dimensions of health problems to a global awareness of environmental conflicts and the social metabolism that underlies unjust international commerce and ecological distribution conflicts.

The conflicts are symptomatic of an unjust system of international commerce in an age of economic globalization (Martinez-Alier 2009). This system implies an international division of labor and risks (Wallerstein, 1979; O’Connor 1998), unequally distributed through the mining (gold, silver, copper, iron, and uranium) (Özkaynak 2012); the exploitation of petroleum, coal, and gas (Acción Ecológica

\footnotetext{
${ }^{2}$ EJOLT (Environmental Justice Organisations, Liabilities and Trade) was funded by the European Union's Seventh Framework Programme for research, technological development and demonstration under grant agreement no 266642 2011-2015). It aimed to improve policy responses to and support collaborative research and action on environmental conflicts through capacity building of environmental justice groups around the world. The free resource library and database are in the website at www.ejolt.org.
} 
2014; Acosta 2013; Badmus 2010; Breilh 2005; Oloruntegbe et al. 2009; Porto 2012a; San Sebastián and Hurtig 2005) the production of industrial metals such as pig iron and brute steel; and the production of agricultural and agro pastoral commodities tied to globalized agribusiness, linked to the intensive use of pesticides and transgenic technologies (ABRASCO 2015); and the location of hazardous industrial and waste facilities. These conflicts impact rural, urban, or traditional populations in the countries of the 'global South', or at the political and economic margins of globalized capitalism - especially in the territories of Latin America, Africa, and Asia that have been subject to colonial and imperial practices for the last few centuries (Santos 2007a 2007b).

How might health be considered from a political ecology view of environmental conflicts and from the perspective of a global movement for environmental justice? This is a complex discussion with various dimensions. Much like risk, health is a polysemic concept. Yet scientific analyses, especially those conducted from within the fields of biomedicine and public health, tend to depoliticize health issues as they de-contextualize the meaning of life, culture, and the struggles of communities and organizations (Rocha and David 2015). For this reason we try to widen the notion of health to reveal its many dimensions, supporting mobilizations for fundamental rights and transformative models of development.

A wider historical context is needed to understand environmental inequality, within and across countries and continents. These inequalities extend beyond the necessary access to environmental resources and healthy environments upon which the most vulnerable and discriminated segments of society depend, as they survive and work on the margins and in "sacrifice zones" (Bullard 1994, 2005). Inequality is multidimensional: social, political, and economic inequalities are reflected in innumerable ways and can be analyzed as a function of discrimination based on social class, gender, race/skin color or ethnicity, or generational divide.

Perceptions of health vary across cultures, but it is reasonable to accept that some variation occurs due to differences in democratic traditions and freedoms, education and labor patterns. Material differences exist in healthy living spaces, air quality, and access to water, land, natural capital, healthy food and basic sanitation (adequate systems of water supply, sewage collection and treatment, and waste disposal). From this perspective, the World Health Organization recognizes that health should be understood in a broad sense, not limited to biomedical functionality, the absence of disease, or increased longevity (WHO 2012). ${ }^{3}$ According to WHO, the determinants of health are the conditions in which people are born, grow, live, work, and age, including the health system, and these social factors are the primary determinants of health inequalities (Marmot 2005).

Such an approach is limited to identifying correlations between social variables and morbidity/mortality events in the population. In so doing, a false impression is created that the protection and promotion of health merely requires the implementation of public redistributive policies that favor a healthy environment and lifestyle. Such an approach, however, risks depoliticizing health issues, as they are transformed into 'risk factors' that can be resolved by decision makers, politicians, and the state bureaucracy, supported by the wide participation of society, and the implementation of 'good' public policies. The predominance of this depoliticized approach is evident in epidemiological studies (Krieger 2001; Pierce 1996, 2008, 2011) and the recurrent use of the notion of governance among health institutions and professionals.

Certain authors prefer to speak of the 'social determination' of health (Breilh 2008; Rocha and David 2015). They argue the current approaches to social determinants are historical and dialectical. In this sense social, environmental, and health inequalities are linked, produced and confronted in a context of contradictions, conflicts, and conquests, including struggles against labor exploitation, racism, and ethnic and gender discrimination. The notion of social determination permits us to establish a dialogue between the field of public or collective health and political ecology by incorporating the notions of social metabolism and unjust international commerce (Martinez-Alier et al. 2014). ${ }^{4}$ In this perspective macro-

\footnotetext{
${ }^{3}$ Among the main conferences in which the WHO has elaborated this viewpoint, are Alma-Ata, now Almaty in Kazakhstan (1978), Ottawa, Canada (1986), Sundsvall, Sweden (1988), Adelaide, Australia (1991) and Jakarta, Indonesia (1997), among others further on.

${ }^{4}$ The emergence of Collective Health is a Latin American, and especially a Brazilian phenomenon. It is connected with the struggle for democracy and with the Health Reform movement influenced by preventive, community, and social medicines in its constitution. The Brazilian Association of Collective Health (ABRASCO) was founded in 1979, and since then interdisciplinary approaches under the influence of critical social sciences have been promoted.
} 
structural processes must be considered to permit understanding of more local processes and contexts in territories where there are inequalities, lack of justice and resistance. A political ecology of health recognizes that macro-structural processes are filtered through different scales, including the nation state and the region and community, and that we should incorporate and articulate these intervening levels between community and world.

\section{Health indicators, vulnerability and environmental justice}

From the scientific and operational points of view, various 'objective' indicators of health, or their absence, were created in the public health sphere through epidemiological studies. A basic tool of public health is the construction on a morbid-mortality profile, based on surveys and statistics that delineate the morbidity profile (the distribution of types of diseases ${ }^{5}$ ) or mortality (the distribution of causes of death) of a population in a given historical period and region. In this way it is possible to discover which health problems prevail in a given region and period (Porto et al. 2015).

We call attention here to three commentaries on the use of health indicators and morbid-mortality profiling of particular relevance to environmental justice movements. The first is that many poorer countries with institutional vulnerabilities do not have health information systems, or when they do, the data is precarious and untrustworthy, with under-reporting of important cases of known diseases. ${ }^{6}$ This can be due to:

- the absence of a national health system, or adequate policymaking;

- the lack of an education and training system for health professionals, especially in remote areas;

- the public find it difficult to provide the data needed for the forms that feed morbidity systems.

All of these factors complicate discussions about the impacts of certain productive activities on health in the absence of official health data prior to, during, and after the beginning of economic activities that pervade the social metabolism of any particular region. Institutional vulnerabilities are produced and maintained exactly because they are successful in hiding harm, and facilitating continued injustices (Porto 2012b). Thus health policies are needed that establish basic services, with adequate human resources, and strategic information systems are necessary to enable the development of diagnostic, control and prevention measures.

A second point refers to the level of aggregation of information. Even where health information systems are trustworthy in terms of morbidity and mortality data, if the lowest level of spatial aggregation is municipal, analyses of differences in spatial distribution of health problems between neighborhoods, or between rural and urban areas will not be possible. This problem is exacerbated for populations that live in geographically dispersed or remote regions, and explains why many times a health diagnosis demands epidemiological studies that are capable of generating more realistic portraits of the problems in an affected territory (McMichael 1999; Pierce 2011).

A third commentary is of special importance to our goal of seeking to understand health from an environmental justice perspective. Reductionism, as we have said, is crucial to the feasibility of the scientific operationalization of health - what is analyzed and measured is that which biomedical science is able to perceive, i.e., death and is most comprehensible causes, officially recognized diseases, or certain symptoms of ailments or dysfunction that do not clearly configure any specific disease. This is why many say that 'health institutions' would be more adequately named 'disease institutions', or relabeled to reflect

There are many social and human sciences professionals in academic and health institutions within the field of Collective Health (Paim 1992).

${ }^{5}$ The International Classification of Diseases and Related Health Problems (also known as the International Classification of Diseases - ICD 10) is published by the World Health Organization (WHO) and aims at standardizing the code of diseases and other health-related problems. The ICD 10 provides codes relative to classifying diseases and a large variety of signs, symptoms, abnormal aspects, complaints, social circumstances and external causes for injuries and diseases. The ICD 10 may be accessed at http://www.datasus.gov.br/cid10/V2008/cid10.htm or http://www.who.int/classifications/icd/en/.

${ }^{6}$ A lack of information or misclassification leads to underreporting of diseases. These are features common to all surveillance systems but especially severe in countries with high institutional vulnerability as in Latin America and Africa. 
their main functions of diagnosing and seeking to cure illness and reduce suffering. In this sense, studies of the general health situation or epidemiological studies should be conducted from a position favorable to denouncing and mobilizing in favor of environmental justice. Such studies could serve to support policies and actions to prevent illnesses, death, or suffering that might be avoidable under better living and working conditions, and different social-environmental dynamics. This is important, especially when injustice is associated with specific environmental and health problems, such as exposure to dangerous chemical pollutants or radioactive agents that provoke cancer and congenital abnormalities. However, such studies are not in themselves sufficient for constructing a vision of health adequate to the epistemological and political needs of an environmental justice perspective (Porto et al. 2015).

This third point helps us to understand the relationship between health and environmental injustice for people living and/or working in vulnerable contexts and unhealthy environments, those full of preventable environmental risks. The notion of vulnerability (Cutter et al. 2003; Füssel 2006; Turner 2003) enables a better contextualization of environmental risks and health problems, by focusing on the historical reasons for a certain social group becoming vulnerable, or in other words, the processes of "vulnerabilization" of a particular territory and its population (Acselrad 2010; Porto 2012b). It is important to distinguish between processes of being made vulnerable, rather than the mere state of vulnerability of populations and communities if we are to recover historic processes affecting social groups and places. This distinction is also important in order to acknowledge social groups as having been subject to a removal of their rights.

Environmental injustice is a situation in which the development of a territory, country or region, whether through economic enterprise or the application (or not) of public policies, permits part of its population to be overwhelmed by environmentally generated risks. Similarly, it can be a situation in which access to natural resources of the territory in which a population lives and works is restricted, violating several human rights including access to working and living quarters, to a clean environment, and to health and enjoyment of culture.

Environmental injustice stems from a devaluation of and discrimination against life, autonomy, and the culture of affected populations in different contexts and moments. This devaluation is expressed in distinct ways:

- in the way that the economic valuation is used to calculate investments;

- in environmental regulations and licensing;

- in substandard modes of social participation especially among affected populations;

- through the exclusion from mainstream recognition of community modes of production and economic practices;

- in the work of monitoring institutions;

- in the organization of health services;

- and last but not least in studies and research on environmental and health problems past, present, and future.

Needless to say, it is strategically preferable to avoid health problems by focusing on prevention and proactive measures to control and impede threats to health, rather than confronting them after they emerge. The unfortunate reality is that environmental conflicts resulting from injustice are interwoven with risks and processes that increase the vulnerability of populations, long before health problems arise. In these cases, attention to the health of those affected and remediation, including legal measures, could help ensure that future problems are avoided, or at least reduced in terms of their intensity. Thus one of the tasks of global environmental justice movements is to promote exchanges of knowledge and experience among affected communities and organizations, including strategies and actions resulting in success as well as failure. In this way mobilizing groups in different regions might anticipate problems and increase their chances of resistance in the face of particular threats and risks. In helping to reduce vulnerability, movements for environmental justice can play a critical role in articulating health with sustainability and human rights (Porto 2012b).

\section{Health as Dignity: a widened view for environmental justice mobilizations}


A broadened vision of health must embrace political, cultural, and human rights dimensions in order to understand and confront the inequality, discrimination and racism that underlies society, and asymmetrical access to environmental resources and decision making. Confronting the economic and political interests of privileged elites means resisting a development model based on unjust commercial activity, by rejecting current forms of development policies, institutional practices, and territorial and environmental administration.

Health is also associated with democratic values and the exercise of fundamental human rights. These rights include the right to alterity (the state of being other or different) and the autonomy to take part in forms of work, learning and production, cultural and spiritual practices, notably related to nature and among indigenous groups, quilombolas, and peasant communities. These peoples live in regions with relatively well preserved ecosystems and who depend on them not only for subsistence, but for cultural and spiritual meaning in their communitarian lives (Porto 2012b).

Inextricably related to the dimensions already mentioned is the cyclical nature of health. Here we refer to the cycles of life that mark childhood, adulthood, and old age, the same processes that lead to suffering, illness and death, as well as producing happiness, pleasure, and dignity. Birth, growth, work, food, learning, love, health care, aging and death, these are all part of living with dignity. A violation of dignity is facilitated when a person or community is in a position of vulnerability, for instance due to social and environmental inequalities and injustices. In this extended vision, health should be understood dialectically and holistically, rather than as a set of protective measures for facing threats, dysfunction, disease, and avoidable deaths (as it is from the points of view of biomedical disciplines and risk analysis). An extended vision of health is fundamentally based on an understanding of processes that promote life, happiness and dignity throughout the cycles of personal, family, and community life (Porto 2012a).

Health is a dynamic, multidimensional, quantitative, adaptive, and evolutionary concept involving potential for human achievement in its physiological, psychic, and spiritual spheres. This conceptualization understands health as processes and conditions that propitiate human beings at various levels of existence and organization (personal, familiar, communitarian and societal). It affects the objectives, achievements, or virtuous cycles of life embedded in cultural and societal values of societies and their various social groups. Besides biomedical dimensions, health therefore possesses irreducible ethical, social, and cultural dimensions. This latter set is subject to ongoing adaptation, negotiation, and conflict within society, depending on how values and interests are related to power structures. This in turn is also dependent upon the distribution of existing resources, including environmental resources upon which human survival depends. ${ }^{7}$

To struggle for health in an environmental justice perspective means, therefore, going beyond restricted visions of health that preclude consideration of its social and cultural dimensions and that fail to consider its relationship with nature and community self-determination. In other words, it is necessary to fight against discrimination, racism, and undemocratic economic logics and practices that produce not only social injustices and morally unacceptable environmental risks, but also disregard alternative ways of life, economy, work, and nature that are not part of Eurocentric, capitalistic and utilitarian visions.

A widened vision of health results in a continual intercultural and interdisciplinary dialogue between distinct kinds of knowledge and cultures (Santos 2007b). Such a vision can strengthen mobilizations for the right to dignity and to life, producing new interactions, argumentations, and political action guided by values such as justice, solidarity, and sustainability. It encompasses a physical as well as psychological, social, ecological, and spiritual concept of health, which helps us confront the neoclassicist model of economics and the development model it engenders. Health possesses an incommensurable nature, just like other values at stake in environmental conflicts, and cannot be apprehended by purely economistic logics (Martinez-Alier et al. 2014). This implies a moral impossibility of interchanging capitals and treating health merely as an output, externality, or a risk that enters into the calculations of costs and benefits, the aim of which is to 'maximize' general welfare.

We see health as a right to life and to dignity. Human dignity is affronted by morally unacceptable risks, by the existence of structural violence, that, just like racism, discrimination, and the way in which health problems are treated and (un)cared for, provokes humiliation. Human dignity is respected and cultivated when, for example, we introduce new meanings and dimensions to the concept of health.

${ }^{7}$ Adapted from Porto (2012a). 
Examples of such instances can be found in conceptions based on the perspectives and necessities of communities, such as the notion of Buen Vivir, or Sumak Kawsay in the Quechua language of the indigenous peoples of South America, who understand 'Living Well' not as living better than others, but as not living at the expense at others (Santos 2013). Some traditional Forest peoples, in contraposition to advancing large-scale monoculture agriculture that reduces and deprives these people of their food products, herbs, and other medicines, in fighting for their rights argue "the Forest is our supermarket" (Chai et al. 2008). In any case we ask, what is living or quality of life without considering meaning, virtue, and dignity of living?

A similar rationale may be applied to notions of rich and poor, which may be extended beyond ownership of material goods to take into consideration the principles of life and dignity: those rich in resources could be indigent, and as such poor of spirit; and the poor, even in difficult situations, can exercise their dignity, and in this sense be rich in human virtues. In the same way, we may widen the notion of health through the re-signifying processes of trans-cultural dialogue and the political struggles of current global movements for environmental justice (Porto 2012b).

\section{Health, political epistemology and the production of knowledge}

Often, collective mobilizations for environmental justice are organized out of suspicion that certain health events - suffering, illness or even death - originate or are intensified by economic and productive activities such as mining, agribusiness, energy production, and industrial activity and the pollution it causes. The type of problems that surface, and when they become manifest, depends on the stage of production in which they occur. These problems can affect the characteristics of ecosystems and availability of resources, such as clean air, water soil and food, and consequently, living and working conditions (Porto 2012c).

Community health suspicions can remain unconfirmed for many years whilst different processes and events trigger the intensification and radicalization of previously latent mobilizations and controversies. These triggers can include the discovery of illness in a loved one in the community, news of a major environmental incident published in the press, access to formal education by affected people, an initiative taken by particularly charismatic locals upon discovering the presence of a local threat, or dissemination of information about environmental or health problems by NGOs, EJOs, social movements, political groups, research groups, teachers/educators, religious leaders or students (Porto 2012a).

At the same time, the discourses of local people are molded by everyday experiences and perceptions of their world as it is transformed around them. For example, speculation about new smells in the air, the gathering of dust in homes and on clothes, changes in the taste of drinking water, and possible correlations with the onset of physical malaise, all become part of conversation and debate that inform the active search for information on these topics in a rich and complex process of collective knowledge construction. Technical and scientific knowledge, to the extent that it is available and accessible, shapes common understanding about problems experienced and observed by people in their daily lives. This construction generates assumptions that correlate with observed environmental and health transformations, stimulating people and EJ organizations to actively search for information, combining different forms of knowledge - with varying degrees of systematization and social acceptability or legitimacy - in dialogue.

In the face of the limitations of predominant scientific approaches in terms of analyzing environmental risks and health problems, several strategies have been developed by affected people and EJ organizations, together with scientists and professional activists, for the production of knowledge (Brown 1987, 1992; Corbun 2005, 2007; Martinez-Alier 2011, 2014; Soliz and Maldonado 2011; Wing 2005). One such strategy aims to progress beyond the classic or "normal" science model that ignores the complexity of the phenomena, and omits consideration of central issues such as uncertainty, values, and the knowledge of populations affected by environmental injustices (Funtowicz and Ravetz 1993). A 'political epistemology' proposes the integration of knowledge production with historical and political contexts. From a perspective of political ecology, a political epistemology takes as its departure point the idea that all knowledge - especially when it involves environmental issues, risks and health effects - is a product of multiple interests and perspectives, as well as values and uncertainties, all of which shape readings of reality and possibilities for problem solving. Thus, knowledge production processes are embedded with an irreducible political dimension that needs to be made explicit and confronted in 
problems related to environmental conflicts and injustices. Our outlook incorporates advances in complexity theory, non-functionalist systems approaches, the work by authors such as Silvio Funtowicz and Jerome Ravetzon Post-Normal Science (1990, 1993), Boaventura de Sousa Santos (2007a, 2007b) and his proposal of an Ecology of Knowledges, and others who support integrated, systemic and participatory approaches for knowledge production, i.e., perceiving and addressing problems in terms of connections, relationships and contexts focused on sustainability and environmental justice.

Recognizing complexity means accepting that a plurality of perspectives and methodologies are necessary and legitimate. This entails taking an integrated approach that can analyze social (or sociotechnical) and human systems, and non-human natural systems related to ecosystems, geophysical systems or climate at different scales from the community to the global. All these dimensions are present in chemical, industrial, and desertification processes, as well as in natural hazards including floods, earthquakes and hurricanes, which are arguably influenced and even aggravated by humans. Whatever the case, a political epistemology means going beyond functionalist, systemic thinking that is focused exclusively on energy and material flows and thermodynamics, and the connections with the biological, ecosystemic and biomedical worlds. Such paradigms may be appropriate to analyze important aspects of problems involving risks and health, but they may hide or dilute the importance of political, ethical and cultural issues, as well as historical and social dimensions of a dialectical nature, such as conflicts and values (Porto 2012b).

A political epistemology for environmental justice also seeks to make explicit the various forms uncertainty takes (Van der Sluijs 2006), sometimes hidden or manipulated in scientific discourses (Porto 2012b). It also means to pointing to implications for understanding problems and possible solutions. In other words, the way in which uncertainties are interpreted may aggravate threats to life, increasing vulnerabilities and injustice.

Paradoxically however, uncertainties can also contribute to the strengthening of environmental justice mobilizations. The relationship between risks, health problems and uncertainty, when made explicit, removes the legitimacy of a specialized peer community to solely define the parameters of a problem and the arguments upon which decisions are based. In linking discussions of risk, health and uncertainty with environmental justice, it is possible to better comprehend how dangerous situations are morally unacceptable. This unacceptability stems from the fact that such situations are preventable, but are ultimately imposed on socially discriminated groups, rendering them more vulnerable and violating their basic human rights. This is why the precautionary principle (COMEST 2005) is so strategic for the promotion of environmental justice (Harari et al. 2004). In other words, incurring type II errors (accepting a technology, process or activity as safe, that in time might prove to be extremely dangerous) is less desirable on the grounds that it brings more harm to life than Type I errors (rejecting a technology or activity on the grounds that it might be unsafe, when in fact the benefits would be greater) (Funtowicz and Ravetz 1993).

The meeting and integration of knowledges, as well as the formation of extended communities for knowledge production, action research and decision-making is a necessary strategy, through the practice of post-normal science for example (Funtowicz and Ravetz, 1990, 1993). Of particular importance is the knowledge and action of affected populations and EJ organizations affected by environmental and health problems. Therefore, it is necessary to combat positivist views that support the idea that legitimate knowledge comes only from disciplines and specialized scientific communities. Although fundamental, such knowledge may be insufficient to support environmental justice mobilizations.

There is a large body of literature with various theoretical and methodological proposals that challenge positivist thinking, promoting for example:

- integrated inter/transdisciplinary approaches;

- citizen, street or activist science;

- action and participatory research;

- combined qualitative-quantitative or triangulation methods;

- social cartography initiatives that combine mapping techniques with participatory activities;

- dialogue and the ecology of knowledges; 
- and the construction of spaces and forums for shared knowledge construction and environmental justice mobilizations (Bronw 1987; Corburn 2005, 2007; Haley 2005; Irwin 1995; Martinez-Alier 2011, 2014; Santos 2007a, 2007b; Solíz and Maldonado 2011; Wing 2005).

All these approaches recognize to a greater or lesser extent, the existence of multiple sources of knowledge beyond the scientific disciplines, and give value to the contextual, situated, popular and cultural knowledge existing in non-scientific communities of workers, traditional peoples and populations exposed to risk situations. These contributions politicize knowledge production by making clear the ethical issues that are at stake. The integration of knowledges, however, poses an enormous challenge, since it implies the construction of engagement processes, mutual trust, exchange of references and intercultural dialogues that shape and converge fields of knowledge and practice (Escobar 1998).

In the classic view in which scientific knowledge is considered superior, the major challenges are:

- to increase dialogue between scientists of various disciplines, decision makers and affected communities;

- to democratize scientific processes and disseminate these findings;

- and to produce knowledge for action through translation, mediation, transfer or exchange activities (Graham et al. 2006).

From the perspective of political epistemology and activist struggles for environmental justice, the superiority of scientific knowledge is seen as integral to a form of domination and colonialism that excludes other world views, cosmologies and epistemologies, and therefore obstructs the construction of other possible futures. Translation, as in the work of Boaventura de Sousa Santos (2010), can be defined as simultaneously an intellectual, political and intercultural task, requiring emotional, subjective engagement in the practice of nonconformity, and the will to overcome the incompleteness of existing knowledge or practices. It is the task of translators to set up communication links not only between scientific paradigms, but cultures, values and languages in search of understanding and with the aim of reframing continuously evolving problems. This is precisely what is required in the case of environmental conflicts and global movement for environmental justice.

Translators circulate among, and to some extent dominate, different epistemologies, paradigms and languages. Exemplary cases are members of specific communities such as indigenous groups, farmers, slum dwellers or industrial workers who undergo technical and scientific training. Other translators are professional environmental educators, community health workers, or even researchers that have engaged with specific communities, environments and cultures for considerable periods of time, establishing dialogues, commitments and convergences through activism, action research or participantobservation. Translators are often members of EJOs, and there is some connections with the concept of 'knowledge brokers' used by Lewis and Mosse to discuss the anthropology of development in order to understand how development projects become real through the work of generating and translating various interests (2006). However, our goal here is more related to knowledge than to subjective interests, although both are always inextricably linked. The academic literature on environmental justice is rich with historical examples of building strategies, conceptual and methodological tools, and political actions around the shared construction of knowledge and 'militant science' (Martinez-Alier et al. 2014). This includes so-called Community Based Participatory Research, originally developed in the USA (Haley 2005; Leung et al. 2004).

In the shared process of knowledge construction, there are countless possible sources of information, and means of organizing and integrating knowledge and practice. Environmental hazards and health problems can be systematically analyzed on the basis of historical academic and professional works (studies published in books, articles and reports), and through other media including journalist narratives, non-academic books, films, literary and artistic productions, personal statements or reports produced in connection with legal proceedings. This can be achieved with the direct participation of affected populations and environmental justice organizations (EJOs) that methodically examine environmental and health problems, past and present. Such works produce inventories, mapping and 
significant narratives of environmental conflict, cases of pollution, disease and death, accidents, disasters and catastrophes related to various economic, productive and technological activities. They also produce and disseminate values, significant experiences and alternatives for other possible worlds, including ways of life, relationships with nature, and economies of solidarity. In addition these works act as an inventory of the performance of institutions and public authorities, including allegations of bias, incomplete risk analysis, and studies of health problems made by institutions and experts.

These works are all part of the dialogue that can converge into mobilization strategies created by people and EJOs in order to confront overcome problems. The sharing of such works and experiences among different EJOs around specific problems - whether at local, national or international scales enables collective learning, thus constituting an important strategy for preventing the occurrence of environmental injustices. For example, participating in decision making, demanding adequate information or the 'Best Available Technologies' (BAT), barring certain dangerous economic or productive activities, intervening in environmental management strategies and risk management, reporting health problems, engaging in the formulation of risk investigation projects or calling for new studies and health services, among other possible actions, all offer ways of improving environmental justice.

There are several currents of criticism developed by militant public health professionals that incorporate the knowledge of workers and vulnerable populations in the production of knowledge. Two of them, which are connected to environmental justice movements, are of particular relevance. The first is the so-called popular epidemiology (Brown 1987, 1992), and the second is community-based participatory research (Haley 2005). Both of these have strong roots in American EJ movements. In addition, a third current, an emergent practice of popular health surveillance can be traced to experiences of participatory health monitoring experiences in Latin America (Breilh 2003; Porto 2012c; Soliz and Maldonado 2011).

A final strategy of importance for analyzing and coping with more complex environmental and health problems, whether at local, regional or global levels, is the articulation of social and intersectoral networks, or forums. The World Social Forum for example, is an important space for the creation of extended communities interested in new forms of collaborative knowledge production. Such spaces work as a political and cultural substrate for the global movement for environmental justice. They enable collaboration and the formation of alliances for the production and dissemination of knowledge, and joint practices and actions. It is in the midst of such practices that the necessary foundations for a transition to a more just and sustainable world can emerge.

Social networks, in our understanding, are flexible structures that propitiate the construction of communities of practice through the integration of communication channels and action strategies. They can establish horizontal commitments and solidarity between people, social movements, and institutions like governmental and nongovernmental organizations, connected around common causes. Working in networks helps us to think in a systemic, caring and responsible way about how to act on socioenvironmental problems. They enable adequate expression of the integral functioning of biological and human life, and the building of bridges between ecological, social and ethical dimensions. The experience of the Brazilian Network for Environmental Justice and numerous environmental justice collectives in other countries, represent concrete examples of spaces and forums in which possibilities converge to overcome the limitations of classic or normal science (Porto 2012c).

\section{Some lessons and challenges from Latin America and Africa}

The cases of environmental conflict previously analyzed in EJOLT regarding oil production and uranium mining in Latin America and Africa reveal innumerable injustices related to the environmental impacts, health problems and the processes that make populations more vulnerable (Porto et al. 2015). They also point to important lessons, offering criticisms and alternatives for mobilization strategies and knowledge in order to contribute to victories for the environmental justice movement. In this section we highlight some lessons and challenges for movements and organizations that work for environmental justice across the world.

The first point we emphasize is that the oppressive decision-making processes related to environmental injustices often disregard the needs and demands of local people in the name of economic progress. The alliance between local and national elites and multinational companies reveals the significant ability of these companies to overcome political instability in defense of their interests. Often 
'national interest' (subordinated to the interests of multinational companies) is prioritized over the economic, environmental and health of communities and peoples inhabiting territories that have gradually been integrated into the increasingly globalized capitalist economy.

In the case of the oil industry in Nigeria and Ecuador, for example, central national governments work out as managers of strategic energy resources that disregard all claims of subnational governments or traditional tribal authorities to managing the costs and benefits of resource exploitation. International and national power relations often result in injustice against local people, who while contributing significantly to the national Gross Domestic Product (GDP) suffer environmental consequences without benefitting from basic services that can mitigate environmental impacts. This reality feeds political and ethnic conflicts, exacerbates social tensions, and in some cases has stimulated the 'nationalism' of ethnic minorities and even extreme measures, such as sabotage, armed struggle, large scale street mobilization and the isolation of some Ecuadorian ethnicities from national society.

Moreover, environmental conflicts in both countries reveal the importance of democracy and community or ethnic organization, and articulation of goals with other national or even international social movements on a global level. These linkages have enabled not only the amplification of the complaints and demands of those affected by environmental impacts on their living conditions and public health, but has also enabled occasional legal and even symbolic victories, innovative strategies of resistance, and rescued the vitality of traditional forms of organization, even though it often develops under constant risk of co-optation of local leaders, violence and political setbacks.

However, these cases also point to the limitations and difficulties of establishing (inter)national regulatory frameworks for the activities of multinational oil companies. This is especially so for those frameworks that take into account both the environmental integrity of ecosystems (as a source of human dignity and healthier ways of life), and the importance of establishing other forms of sustainable and solitary economies. It seems clear that the environmental injustices produced in these territories are the result of the relationship between global economic groups that benefit from a capitalist economic structure, which are increasingly predatory from a social and environmental view. These conglomerates often act in an authoritarian manner in societies still marked by colonial relations, and also tend to be highly dependent on forms of neoextractivism.

Another important lesson that can be derived from the analysis of these cases, especially with reference to the case of Ecuador, is the importance of the engagement of scientists and research groups sensitive to the problems faced by communities. This is essential to:

(1) establishing alternative and participatory research methods when official data fail or are nonexistent, or when the hegemonic epidemiological / scientific analyses inadequately consider the complexity and knowledge gaps involved in conflicts and their consequences;

(2) build arenas of persuasion and dispute decision making - mostly legal - so that the knowledge generated by such research methodologies is not wasted, and becomes part of the legitimate strategies of argumentation of actors in those spaces. This is especially vital for establishing causal links between productive activities and environmental impacts, and between them and the damage to the health of populations made vulnerable or deaths generated by such processes.

In this context, it is vital to establish causal links between productive activities and their social and environmental impacts, as well as on the health of populations affected by such processes. It is therefore important to restructure the national health system in these communities, so that they can identify the health needs of affected communities and formulate public policies related to the effects of environmental contamination. The cases analyzed in Latin America and Africa show huge institutional weaknesses to date in this regard.

In Latin America and Africa, companies often adopt technologies and forms of management that have long since been abandoned in their countries of origin, and fail to implement basic environmental risk management measures. Corporations also take advantage of weak social and environmental legislation to improve their competitiveness, engaging in social and environmental 'dumping.' While more rigorous environmental, occupational and territorial regulation is clearly needed, there is also a need for 
mobilization to confront the grand scale of environmental damage already generated, some of which poses a tremendous challenge in terms of mitigation and/or management. Financial compensation, while it plays a role in strengthening affected communities, is often not sufficient given the extent of ecological impacts and the profound consequences for the livelihoods of affected peoples.

Another strategic task for these movements is the deconstruction of the corporate discourse of socio-environmental responsibility. This can be achieved by communicating the experiences of their struggles and the environmental injustices they have been subjected to, and by drawing attention to the impacts of vertically imposed local development projects, 'green' marketing efforts, or other greenwashing practices, such as the promotion of corporate initiatives that ultimately generate environmental conflicts and injustices.

\section{Final considerations}

From the viewpoint of political epistemology, the environmental conflicts reviewed here highlight how various social and political processes ultimately undermine environmental sustainability and unfairly expose local communities to environmental injustices. As we have shown, these activities expose people to pollutants that affect their health, making them vulnerable to cancer, respiratory diseases, infertility, malnutrition and increasingly to violence, to the point that many of these communities have begun to be decimated by acute, chronic diseases and the physical weaknesses associated with extreme poverty.

The principal duality portrayed in this article highlights a conflict between the supremacy of life versus economic interests. In the name of progress and profit, the latter annihilate life in various ways. Mobilisations for environmental justice question bio-medical logics, and the way that they restrict perceptions of health to quantifiable measures of death and disease. In contrast, we understand health to be an incommensurable value, a fundamental right that concerns the dignity of the human being and of the peoples throughout the world.

Environmental justice movements have taken on a broader vision of health in their relationship to social, ecological, cultural and spiritual production of life. In this sense, health, democracy and well-being are connected and must have first priority over private property and excessively economic oriented social policies. Similarly, the socio-diversity and vitality of ecosystems must be preserved. This includes a full and unrestricted guarantee of human rights. These rights must go beyond mere formal equality, or the guarantee of just civil and political rights. While such rights are of extreme importance in countries especially from Latin America, Africa and Asia, where conservative and authoritarian practices persist, these rights alone are insufficient without the simultaneous guarantee of ecological, cultural, economic and social rights. This latter group of rights constitutes a sine qua non condition for an emancipatory promotion of public health, environmental justice and fundamental and inalienable rights of all individuals, families, and communities who suffer the negative consequences of global capitalism.

We do not associate the notion of health as a right with any sort of radically universalist (or colonialist) vision of human rights that extinguishes cultural differences and the specifics of diverse social groups in the name of a certain vision of humanity. On the contrary, we understand that rights only become realised when alterity is respected and different social groups have autonomy over social organisation, management of internal conflicts, strategic aims, and territorial exploitation. Ensuring socioenvironmental sustainability and the health of vulnerable populations does not mean imposing hegemonic conceptions of the environment, body, humanity and health, but rather, constructing the conditions necessary for dialogue with different communities and respecting their traditional practices and forms of knowledge. Yet, this must also occur without falling into exaggerated relativism that justifies atrocities due to local traditions. Inter-cultural dialogue must allow that both sides reformulate their ideas and viewpoints so as to broaden their mutual respect, equal rights and human dignity.

Finally, knowledge production is of great importance for environmental justice mobilizations. There is a great imbalance in the way large corporations, often working hand in hand with governmental and university institutions, produce knowledge to serve their own economic interests. Such findings place no value on the evaluation of environmental and health impacts, establishing a causal nexus, or questioning the resultant decisions taken by governments. It is therefore necessary to strengthen partnerships with researchers, universities and research institutes, in order to deconstruct arguments that are shaped by economic interests, and that tend to exonerate companies from responsibility for environmental and health problems. No matter how well-intended, the cooperation of researchers and 
specialists alone is often not sufficient to deliver environmental justice. As we have already argued, the classic or normal model of science tends to exclude traditional cultural values and omit uncertainties, using the pretense of scientific neutrality and objectivity. It is therefore crucial that cooperative researchers focus their efforts on establishing alternative and participative research methods, and on coconstructing new, transdisciplinary and intercultural knowledge.

\section{References}

ABRASCO. 2015. Dossiê ABRASCO: um alerta sobre os impactos dos agrotóxicos na saúde. http://abrasco.org.br/dossieagrotoxicos

Acción Ecologica. 2014. Pueblos Indígenas y petroleras. Tres Miradas: http://www.clinicambiental.org/docs/publicaciones/3historiasweb.pdf

Acosta, A., 2013. La Iniciativa ITT-Yasuní o la compleja construcción de la utopia. Energía y equidad http://energiayequidad.org/blog/?p=125\#more-125.

Acselrad, H. 2010. Vulnerabilidade, processos e relações. In Ferreira, H. (ed.). Estado de direito ambiental: tendências. 2nd ed. Rio de Janeiro: Forense Universitária. Pp. 95-103.

Badmus, I.A. 2010. Oiling the guns and gunning for oil: oil violence, arms proliferation and the destruction of Nigeria's Niger-Delta. Journal of Alternative Perspectives in the Social Sciences 2(1): 323-363.

Breilh J. 2003. De la vigilancia convencional al monitoreo participativo. Ciência \& Saúde Coletiva 8(4): 937-951.

Breilh, J. 2008. Latin American critical ('social') epidemiology: new settings for an old dream. International Journal of Epidemiology 37(4): 745-750.

Breilh, J. 2005. Texaco y sus consultores. International Journal of Occupational and Environmental Health 11(2): 217-220.

Brown P. 1992. Popular epidemiology and toxic waste contamination: lay and professional ways of knowing. Journal of Health and Social Behaviour 33(3): 267-281.

Brown P. 1987. Popular epidemiology: community response to toxic waste-induced disease in Woburn, Massachusetts. Science, Technology, and Human Values 12: 78-85.

Bullard R.D. 1994. Dumping in Dixie: race, class and environmental quality. Boulder: Westview Press.

Bullard, R.D. 2005. The quest for environmental justice: human rights, and the politics of pollution. San Francisco: Sierra Club Books.

COMEST. 2005. The precautionary principle. Paris: World Commission on the Ethics of Scientific Knowledge and Technology (COMEST), United Nations Educational, Scientific and Cultural Organization (UNESCO) http://unesdoc.unesco.org/images/0013/001395/139578e.pdf

Corburn J. 2005. Street science: community knowledge and environmental health justice. Cambridge: MIT Press.

Corburn J. 2007. Community knowledge in environmental health science: co-producing policy expertise. Environmental Science and Policy 10(2): 150-161. Researchgate

Cutter, S.L., B.J. Boruff and W.L. Shirley. 2003. Social vulnerability to environmental hazards. Social Science Quarterly 84(2): 242-261.

Funtowicz, S.O. and J.R. Ravetz. 1990. Uncertainty and quality in science for policy. Dordrecht: Kluwer.

Funtowicz S and J. Ravetz. 1993. Science for the post-normal age. Futures 25 (7): 739-755.

Füssel, H.-M. 2006. Vulnerability: a generally applicable conceptual framework. Global Environmental Change 17: 155-167.

Haley E. 2005. Methods to help communities investigate environmental health issues. Pimatisiwin: $a$ Journal of Aboriginal and Indigenous Community Health 3(1): 34-58.

Harari A.R., R.F. Morales and F.H. Harari. 2004. Major concerns in developing countries: applications of the Precautionary Principle in Ecuador. International Journal of Occupational Medicine And Environmental Health 17(1): 187-192.

Hornborg, A., J.R. McNeill and J. Martinez-Alier. 2007. Rethinking environmental history: world-system history and global environmental change. Lanham: Altamira Press. 
Irwin A. 1995. Citizen science: a study of people, expertise and sustainable development. New York: Routledge.

Krieger, N. 2001. Theories for social epidemiology in the 21st century: an ecosocial perspective. International Journal of Epidemiology 30 (4): 668-677.

Leung M.W., I.H. Yen and M. Minkler. 2004. Community-based participatory research: a promising approach for increasing epidemiology's relevance in the 21st century. International Journal of Epidemiology 33: 499 - 506.

Lewis D. and D. Mosse (eds). 2006. Development brokers and translators: the ethnography of aid and agencies. Bloomfield: Kumarian Press.

Marmot, M. 2005. Social determinants of health inequalities. The Lancet 365(9464): 1099-1104.

Martinez-Alier, J. 2009. Social metabolism, ecological distribution conflicts, and languages of valuation. Capitalism Nature Socialism 20(1): 58-87.

Martinez-Alier, J., H. Healy, L. Temper, M. Walter, B. Rodriguez-Labajos, J.F. Gerber and M. Conde 2011. Between science and activism: learning and teaching ecological economics with Environmental Justice Organisations. Local Environment 16(1): 17-36. draft

Martinez-Alier, J., I. Anguelovski, P. Bond, D. Del Bene, F. Demaria, J.F. Gerber, L. Greyl, W. Haas, H. Healy, V. Marín-Burgos, G. Ojo, M.F. Porto, L. Rijnhout, B. Rodríguez-Labajos, J. Spangenberg, L. Temper, R. Warlenius and I. Yánez. 2014. Between activism and science: grassroots concepts for sustainability coined by environmental justice organizations. Journal of Political Ecology 21: 19-60.

O'Connor J.R. 1998. Natural causes: essays in ecological Marxism. New York: Guilford Press.

Oloruntegbe, K.O., Akinsete, M.A., Odutuyi, M.O., 2009. Fifty years of oil exploration in Nigeria: physico-chemical impacts and implication for environmental accounting and development. Journal of Applied Sciences Research 5(12): 2131-2137.

Özkaynak, B. and B. Rodríguez-Labajos (eds.). 2012. Mining conflicts around the world: common grounds from environmental justice perspective. EJOLT Report No. 7.

Paim J.S. 1992. Collective health and the challenges of practice. In Pan American Health Organization (PAHO). The crisis of public health: reflections for the debate. Washington: Pan American Health Organization. Pp. 136-150.

Pierce N. 1996. Traditional epidemiology, modern epidemiology, and public health. American Journal of Public Health 86(5): 678-683.

Pierce N. 2008. Corporate influences on epidemiology. International Journal of Epidemiology 37:46-53.

Pierce N. 2011. Epidemiology in a changing world: variation, causation and ubiquitous risk factors. International Journal of Epidemiology 40:503-512.

Porto M.F. 2012a. Uma ecologia política dos riscos: princípios para integrarmos o local e o global na promoção da saúde e da justiça ambiental. 2nd ed. Rio de Janeiro: Ed. Fiocruz.

Porto M.F. 2012b. Complexity, vulnerability processes and environmental justice: an essay in political epistemology. RCCS Annual Review: a selection from the Portuguese journal Revista Crítica de Ciências Sociais 4.

Porto, M.F. 2012c. Movements and the network of environmental justice in Brazil. Environmental Justice 5(2): 100-104.

Porto, M.F., R. Finamore and D. Rocha, 2015. Health as dignity: risks, health and mobilizations for environmental justice. EJOLT Report 19. 147 p.

Rocha, P.R. and H.M.S.L. David. 2015. Determination or determinants? A debate based on the theory on the social production of health. Revista da Escola de Enfermagem da USP 49(1): 129-135.

San Sebastián, M. and A.K. Hurtig. 2005. Oil development and health in the Amazon basin of Ecuador: the popular epidemiology process. Social Science and Medicine 60: 799-807.

Santos, B.S. 2007a. Beyond abyssal thinking: from global lines to ecologies of knowledges. Review, a Journal of the Fernand Braudel Center XXX(1): 45-89.

Santos, B.S. 2007b. Cognitive justice in a global world: prudent knowledges for a decent life. Lexington Books. 
Solíz, F. and A. Maldonado. 2011. Guía de metodologías comunitarias participativas. Quito: Clínica Ambiental.

Turner, B.L. II, R.E. Kasperson, P.A. Matson, J.J. McCarthy, R.W. Corell, L. Christensen, N. Eckley, J.X. Kasperson, A. Luerse, M.L. Martellog, C. Polsky, A. Pulsipher, and A. Schiller. 2003. A framework for vulnerability analysis in sustainability science. Proceedings of the National Academy of Sciences of the United States of America 100(14): 8074-8079.

Van der Sluijs, J.P. 2006. Uncertainty, assumptions, and value commitments in the knowledge-base of complex environmental problems. In Guimarães Pereira Â., S. Guedes Vaz and S. Tognetti (eds.) Interfaces between science and society. London: Greenleaf Publishing.

Wallerstein, I. 1979. The capitalist world-economy. Cambridge: Cambridge University Press.

WHO. 2012. What are social determinants of health? Geneva: World Health Organization.

Wing S. 2005. Environmental justice, science and public health. In Goehl T.J. (ed.) Essays on the future of environmental health research: a tribute to Dr. Kenneth Olden. Researgh Triangle Park, NC: National Institue of Environmental Health Sciences. Pp. 54-63. 